\title{
ASURANSI SYARIAH DI INDONESIA (Studi Tentang Peluang ke Depan Industri Asuransi Syariah)
}

\section{Arif Effendi}

STAIMUS Surakarta

arifeffendy34@yahoo.com

\begin{abstract}
The term of takaful originates from Arabic verb "kafalah" which means "to help one another" or "mutual guarantee". Now takaful can be defined as an Islamic insurance concept which is grounded in Islamic muamalat, and regulations of Islamic law. This concept has been practiced in various forms. Theoretically, Takaful is perceived as cooperative or mutual insurance, where members contribute a certain sum of money to a common pool. Takaful is invited since commercial/conventional insurance is prohibited in Islamic law. Commercial/conventional insurance is strictly disallowed for Moslem because it contains the elements of gharar (uncertainty), maysir (gambling), and riba (usury).

Islamic Insurance or Sharia Insurance is based on mutual cooperation, responsibility, assurance, protection and assistance between groups of participants. Sharia Insurance gives members the opportunity to benefit in two ways; from the financial security of a risk sharing arrangement, and from the spiritual benefit. Indonesia Islamic Insurance Association (AASI) said the growth of Takaful industry in 2013 reached 30-40 per cent. This year is expected better than before because Indonesia has prospect for the insurance industry to grow.
\end{abstract}

Keywords : Islamic Law, Risk Sharing, Mutual Cooperation 
72 Arif Effendi

\section{A. Pendahuluan}

Sebagaimana diamanatkan oleh Pancasila dan Undang-Undang Dasar Negara Republik Indonesia Tahun 1945, tujuan pembangunan nasional adalah terciptanya masyarakat adil dan makmur berdasarkan demokrasi ekonomi, dengan mengembangkan sistem ekonomi yang bertumpu pada mekanisme pasar yang berkeadilan. Guna mewujudkan tujuan tersebut, pelaksanaan pembangunan ekonomi nasional diarahkan pada perekonomian yang berpihak pada ekonomi kerakyatan, merata, mandiri, handal, berkeadilan, dan mampu bersaing di kancah perekonomian internasional.

Salah satu bentuk penggalian potensi dan wujud kontribusi masyarakat dalam perekonomian nasional tersebut adalah pengembangan sistem ekonomi berdasarkan nilai Islam (syariah) dengan mengangkat prinsip-prinsipnya ke dalam sistem hukum nasional. Prinsip syariah berdasarkan pada nilai-nilai keadilan, kemanfaatan, keseimbangan, dan keuniversalan (rahmatan lil 'alamin). Prinsip syariah merupakan bagian dari ajaran Islam yang berkaitan dengan ekonomi. Salah satu prinsip dalam ekonomi Islam adalah larangan riba dalam berbagai bentuknya.

Kegiatan usaha yang berdasarkan pada prinsip syariah antara lain adalah kegiatan usaha yang tidak mengandung unsur:

Riba, yaitu penambahan pendapatan secara tidak sah (bathil) antara lain dalam tansaksi pertukaran barang sejenis yang tidak sama kualitas, kuantitas, dan waktu penyerahan (fadhl), atau dalam transaksi pinjam-meminjam yang mempersyaratkan nasabah penerima fasilitas mengembalikan dana yang diterima melebihi pokok pinjaman karena berjalannya waktu (nasiah) ;

Maysir, yaitu transaksi yang digantungkan kepada suatu keadaan yang tidak pasti dan bersifat untung-untungan ;

Gharar, yaitu transaksi yang objeknya tidak jelas, tidak dimiliki, tidak diketahui keberadaannya, atau tidak dapat diserahkan pada saat transaksi dilakukan kecuali diatur lain dalam syariah ;

Haram, yaitu transaksi yang objeknya dilarang dalam syariah ;

Zalim, yaitu transaksi yang menimbulkan ketidakadilan bagi pihak lainnya. ${ }^{1}$

Munculnya asuransi syariah di dunia Islam didasarkan adanya anggapan yang menyatakan bahwa asuransi yang ada selama ini, yaitu asuransi konvensional banyak mengandung unsur riba, maysir, dan gharar.

Dalam hal riba, semua asuransi konvensional menginvestasikan semua dananya dengan bunga, yang berarti selalu melibatkan diri dalam riba. Hal demikian juga dilakukan saat perhitungan kepada peserta, dilakukan dengan menghitung keuntungan di depan. Sedangkan yang dimaksud maysir dalam asuransi konvensional adalah apabila pemegang polis asuransi jiwa meninggal dunia sebelum periode akhir polis asuransinya dan telah membayar preminya sebagian, maka ahli waris akan menerima sejumlah uang tertentu. Pemegang polis tidak

1 Penjelasan Pasal 2 atas Undang-Undang No 21 tahun 2008 tentang Perbankan Syariah 
mengetahui bagaimana dan darimana cara perusahaan asuransi konvensional membayarkan uang pertanggungannya. Sementara itu gharar terjadi pada asuransi konvensional, dikarenakan tidak adanya batas waktu pembayaran premi yang didasarkan atas usia tertanggung. Jika baru sekali seorang tertanggung membayar premi ditakirkan meninggal, perusahaan asuransi akan rugi sementara pihak tertanggung merasa untung secara materi. Jika tertanggung dipanjangkan usianya, perusahaan asuransi akan untung dan pihak tertanggung merasa rugi secara finansial

Adapun yang dimaksud dengan syariah menurut penjelasan pasal 49 huruf i UndangUndang Nomor 3 tahun 2006 tentang Peradilan Agama adalah perbuatan atau kegiatan usaha yang dilaksanakan menurut prinsip syariah antara lain meliputi : bank syariah ; lembaga keuangan mikro syariah ; asuransi syariah ; reasuransi syariah ; reksadana syariah ; obligasi syariah dan surat berharga jangka menengah syariah ; sekuritas syariah ; pembiayaan syariah ; pegadaian syariah ; dana pensiun lembaga keuangan syariah ; dan bisnis syariah. ${ }^{2}$

Asuransi syariah adalah salah satu kegiatan usaha yang dilakukan menurut prinsip syariah. Kajian mengenai asuransi syariah mengemuka tatkala dunia Islam tertarik untuk mengkaji secara mendalam apa dan bagaimana cara mengaktualisasikan konsep ekonomi syariah. Asuransi syariah disebut juga dengan asuransi ta'awun yang artinya tolong-menolong atau saling membantu. Oleh karenanya dapat dikatakan bahwa asuransi ta'awun prinsip dasarnya adalah dasar syariat yang saling toleran terhadap sesama manusia untuk menjalin kebersamaan dalam meringankan bencana yang mungkin dialami. Asuransi syariah dengan prinsip ta'awun mulai berkembang pesat di Indonesia pada beberapa tahun terakhir.

Asuransi syariah di Indonesia dapat dikatakan tumbuh pesat, seiring dengan perkembangan industri keuangan syariah pada umumnya, seperti bank syariah. Asuransi syariah di Indonesia sendiri mulai lahir tahun 1994, dengan berdirinya Asuransi Takaful Indonesia pada 25 Agustus 1994 dengan produk Asuransi Takaful Keluarga (life insurance). Sejak saat itu, beberapa perusahaan asuransi syariah yang lain mulai mengikuti jejak Asuransi Takaful Indonesia dengan membuka unit usaha syariah. Gagasan untuk mendirikan asuransi Islam di Indonesia sebenarnya telah lama muncul, dan pemikiran tersebut lebih menguat pada saat diresmikannya Bank Muamalat Indonesia pada tahun 1992.

Secara historis, asuransi tidak pernah terjadi (ada) pada zaman Nabi Muhammad SAW, sahabat, dan tabiin. Asuransi pertama kali terjadi pada tahun $1182 \mathrm{M}$ ketika orang-orang Yahudi diusir dari Perancis, untuk menjamin resiko barang-barang mereka yang diangkut lewat laut. Pada tahun $1680 \mathrm{M}$ di London diadakan lembaga asuransi kebakaran karena kebakaran yang terjadi pada 1666 telah menghanguskan sekitar 13.000 rumah dan 100 buah gereja. $^{3}$

Secara umum pendapat ulama secara perorangan mengenai asuransi dapat dibedakan menjadi tiga, yaitu ulama yang mengharamkan asuransi, ulama yang menghalalkan asuransi, dan ulama yang memerinci jenis-jenis asuransi sehingga pendapatnya beragam. Diantara ulama

2 Penjelasan pasal 49 huruf i atas Undang-Undang Nomor 3 tahun 2006 tentang Peradilan Agama

3 Ahmad Azhar Basyir, dalam Laporan Penelitian Asuransi Syariah, Badan Litbang Diklat Kumdil Mahkamah Agung RI, 2009 
yang mengharamkan asuransi adalah Ibn Abidin al-Hanafi. Diantara ulama yang menghalalkan asuransi adalah Muhammad Abduh dan Mushthafa Muhammad al-Zarqa ; dan diantara ulama yang memerinci asuransi sehingga hukumnya beragam adalah Muhammad Abu Zahrah. ${ }^{4}$

Masa depan asuransi syariah di Indonesia masih sangat terbuka luas, mengingat beberapa alasan. Pertama, Indonesia adalah negara yang menempati jumlah penduduk yang beragama Islam terbesar di dunia. Kedua, Pertumbuhan ekonomi yang kuat dikombinasikan dengan naiknya tingkat tabungan dan berkembangnya perekonomian kelas menengah merupakan pertanda yang baik untuk tumbuh dan berkembangnya industri asuransi terutama yang berbasis syariah. Pasar asuransi syariah di Indonesia terbilang pasar yang belum tergarap dan memiliki peluang yang cukup besar. Tulisan berikut akan melihat Bagaimana peluang ke depan perkembangan industri asuransi yang berbasis syariah di Indonesia.

\section{B. Pembahasan}

\section{Beberapa Pandangan Ahli terhadap Asuransi}

Asuransi atau pertanggungan merupakan lembaga keuangan bukan bank yang hingga saat ini masih menimbulkan pro dan kontra di kalangan para ahli hukum Islam. Hal ini lebih disebabkan karena di dalam Al Qur'an dan Hadits tidak ada satupun ketentuan yang secara eksplisit mengatur tentang asuransi. Perihal asuransi dalam hukum Islam termasuk bidang hukum iftidadiyah artinya untuk menentukan apakah asuransi itu halal atau haram masih diperlukan akal pikiran para ulama ahli fiqih melalui ijtihad. Pendapat yang dikemukakan oleh para ahli berkisar pada pembolehan semua bentuk asuransi ; ada yang membolehkan khusus hanya untuk asuransi sosial dan mengharamkan asuransi yang bersifat komersial ; dan ada yang sama sekali melarang dan mengatakan bahwa hukum dari asuransi adalah haram.

Pendapat para ahli hukum Islam terhadap asuransi dapat dikelompokkan dalam empat pandangan, yaitu:

a. Pandangan yang mengatakan bahwa asuransi itu haram dalam segala macam bentuknya, baik asuransi sosial maupun asuransi komersial. Pandangan ini dikemukakan oleh Sayyid Abdullah Al Qalqili (mufti Yordania), Yusuf Qardhawi dan Muhammad Bakhit Al Mutha' (mufti Mesir). Menurut pandangan kelompok ini, asuransi diharamkan karena beberapa alasan:

1) Asuransi mengandung unsur perjudian (maysir) yang dilarang di dalam Islam

2) Asuransi mengandung unsur ketidakpastian (gharar)

3) Asuransi mengandung unsur riba/renten yang secara jelas dan tegas dilarang dalam Islam

4) Asuransi mengandung unsur pemerasan yang bersifat menekan, karena pemegang polis apabila tidak bisa melanjutkan pembayaran preminya, maka premi yang sudah dibayarkan akan hangus atau dikurangi

5) Premi-premi yang sudah dibayarkan seringkali akan diputar dalam praktik-praktik riba

4 Ahmad Azhar Basyir, dalam Laporan Penelitian Asuransi Syariah, Badan Litbang Diklat Kumdil Mahkamah Agung RI, 2009 
6) Asuransi termasuk jual-beli atau tukar-menukar mata uang yang bersifat tidak tunai (akad sharf)

7) Pada asuransi jiwa, hidup matinya manusia dijadikan sebagai obyek bisnis yang berarti mendahului takdir Allah. ${ }^{5}$

Sayyid Sabiq dalam Fakih Sunnah jilid 13 menyatakan bahwa asuransi tidak termasuk mudharabah yang shahih, melainkan mudharabah yang fasid yang tentu hukumnya secara syara' bertentangan dengan hukum akad asuransi ditinjau dari segi undang-undang. Hal ini terjadi karena tidak mungkin dapat dikatakan bahwa perusahaan (syirkah) menyumbang orang yang mengasuransikan dengan pembayarannya. Akad asuransi ditinjau dari aturan mainnya adalah akad perolehan berdasarkan perkiraan. ${ }^{6}$

b. Pandangan yang mengatakan bahwa Asuransi hukumya halal atau diperbolehkan dalam Islam. Pandangan ini dikemukakan oleh Abdul Wahab Khalaf, Mustafa Ahmad Zanqa (Guru Besar Hukum Islam Universitas Cairo Mesir), Muhammad Nejatullah Siddiqi, dan Abdurahman Isa. Adapun beberapa alasan yang mereka kemukakan adalah :

1) Tidak ada nash (Al Qur'an dan Sunnah) yang secara jelas dan tegas melarang kegiatan asuransi

2) Ada kesepakatan dan kerelaan kedua belah pihak, baik penanggung maupun tertanggung

3) Saling menguntungkan kedua belah pihak

4) Asuransi dapat berguna bagi kepentingan umum, sebab premi yang terkumpul dapat diinvestasikan untuk proyek-proyek yang produktif dan pembangunan. Dengan kata lain kemaslahatan dari usaha asuransi lebih besar daripada mudharatnya.

5) Asuransi dikelola berdasarkan akad mudharabah (bagi hasil)

6) Asuransi termasuk kategori koperasi (syirkah taawuniayah)

7) Asuransi dianalogikan (diqiyaskan) dengan dana pensiun, seperti Taspen. ${ }^{7}$

c. Pendapat yang mengatakan bahwa asuransi yang bersifat sosial dibolehkan dan yang bersifat komersial diharamkan. Pendapat ini antara lain dianut oleh Muhammad Abu Zahrah (Guru Besar Universitas Cairo Mesir). Alasan yang mengatakan asuransi yang bersifat sosial dibolehkan karena jenis asuransi sosial tidak mengandung unsur-unsur yang dilarang di dalam Islam. $^{8}$

d. Pandangan yang mengatakan bahwa asuransi adalah subhat. Alasannya adalah karena tidak ada dalil yang menyatakan secara tegas bahwa asuransi adalah haram, begitu pula tidak ada dalil yang menyatakan bahwa asuransi dibolehkan. Dalam Islam, apabila berhadapan dengan hukum yang sifatnya subhat adalah lebih baik ditinggalkan.

5 Warkum Sumitro, dalam Abdul Ghofur Anshori, Asuransi Syariah di Indonesia (Regulasi dan Operasionalisasinya di dalam Kerangka Hukum Positif di Indonesia,2007, UII Press, Yogyakarta, hal 10

6 Sayyid Sabiq dalam Abdul Ghofur Anshori, Asuransi Syariah di Indonesia (Regulasi dan Operasionalisasinya di dalam Kerangka Hukum Positif di Indonesia,2007, UII Press, Yogyakarta, hal 11

7Warkum Sumitro, dalam Abdul Ghofur Anshori, Asuransi Syariah di Indonesia (Regulasi dan Operasionalisasinya di dalam Kerangka Hukum Positif di Indonesia,2007, UII Press, Yogyakarta, hal 11-12

8 Warkum Sumitro, dalam Abdul Ghofur Anshori, Asuransi Syariah di Indonesia (Regulasi dan Operasionalisasinya di dalam Kerangka Hukum Positif di Indonesia),2007, UII Press, Yogyakarta, hal 12

9 Warkum Sumitro, dalam Abdul Ghofur Anshori, Asuransi Syariah di Indonesia (Regulasi dan Operasionalisasinya 
Walaupun dalam Islam tidak ada dasar hukum yang secara eksplisit dapat dijadikan pedoman mengenai asuransi, akan tetapi dalam $\mathrm{Al}$ Qur'an dan Hadits terdapat beberapa prinsip yang dapat diterapkan dalam perjanjian asuransi antara perusahaan asuransi dengan peserta asuransi. Oleh karena itu, untuk memenuhi kebutuhan dan menjawab pertanyaan masyarakat, Dewan Syariah Nasional memandang perlu menetapkan fatwa tentang asuransi yang berdasarkan prinsip-prinsip syariah untuk dijadikan pedoman oleh pihak-pihak yang memerlukannya. Pertimbangan yang lain adalah dalam menyongsong masa depan dan upaya mengantisipasi kemungkinan terjadinya resiko dalam kehidupan ekonomi yang akan dihadapi, perlu dipersiapkan sejumlah dana tertentu sejak dini. Akhirnya Majelis Ulama Indonesia menetapkan Fatwa Dewan Syariah Nasional No : 21/DSNMUI/X/2001.

\section{Aturan Hukum tentang Asuransi Syariah di Indonesia}

Dalam sosiologi hukum, dikatakan bahwa hukum dapat berlaku secara yuridis dan secara sosiologis. Berlaku secara sosiologis artinya hukum dapat dipaksakan keberlakuannya oleh penguasa meskipun masyarakat menolaknya (teori kekuasaan) atau hukum berlaku karena diterima dan diakui oleh masyarakat (teori pengakuan). Disamping itu hukum dapat berlaku secara filosofis apabila hukum telah menjadi kaedah yang dicita-citakan (ius constituendum). Usaha dengan sistem syariah telah mendapat tempat yang layak di Indonesia baik secara filosofis, yuridis, dan sosiologis.

Secara yuridis, pedoman untuk menjalankan usaha asuransi berdasarkan prinsip syariah bersandar pada Fatwa Dewan Syariah Nasional No : 21/DSN/MUI/X/2001 tentang Pedoman Umum Asuransi Syariah. Dalam Fatwa tersebut yang dimaksud dengan Asuransi Syariah (Tamin, Takaful, atau Tadhamun) adalah usaha saling melindungi dan tolong menolong diantara sejumlah orang/pihak melalui investasi melalui aset dan/atau tabarru' yang memberikan pola pengembalian untuk menghadapi resiko tertentu melalui akad (perikatan) yang sesuai dengan syariah. ${ }^{10}$ Akad yang sesuai dengan syariah yang dimaksud adalah yang tidak mengandung gharar (penipuan), maysir (perjudian), riba, zhulm (penganiayaan), rusywah (suap), barang haram dan maksiat. ${ }^{11}$ Namun demikian, fatwa tersebut tidak memiliki kekuatan hukum dalam Hukum Nasional Indonesia, karena tidak termasuk dalam peraturan perundang-undangan di Indonesia berdasarkan Pasal 7 ayat (1) Undang-Undang Nomor 10 tahun 2004 tentang Pembentukan Peraturan Perundang-Undangan. Jenis dan hierarki Peraturan Perundang-undangan yang diakui dalam Hukum Nasional Indonesia adalah : Undang-Undang Dasar Negara Republik Indonesia Tahun 1945; Undang-Undang/Peraturan Pemerintah Pengganti Undang-Undang; Peraturan Pemerintah; Peraturan Presiden; Peraturan Daerah. ${ }^{12}$

\footnotetext{
di dalam Kerangka Hukum Positif di Indonesia),2007, UII Press, Yogyakarta, hal 12

10 Ketentuan umum angka 1 Fatwa Dewan Syariah Nasional No : 21/DSN/MUI/X/2001 tentang Pedoman Umum Asuransi Syariah.

11 Ketentuan umum angka 2 Fatwa Dewan Syariah Nasional No : 21/DSN/MUI/X/2001 tentang Pedoman Umum Asuransi Syariah.

12 Pasal 7 ayat (1) Undang-Undang Nomor 10 tahun 2004 tentang Pembentukan Peraturan PerundangUndangan.
} 
Data yang diperoleh dari Asosiasi Asuransi Syariah Indonesia, sampai dengan tahun 2012 telah tercatat tiga perusahaan asuransi jiwa syariah, dua asuransi umum syariah, 17 unit asuransi jiwa syariah, dan 20 unit asuransi umum syariah. Dari data tersebut memperlihatkan secara sosiologis bahwa masyarakat Indonesia telah menerima dan mengakui akan keberadaan asuransi syariah di Indonesia.

\section{Dalil-dalil dalam Asuransi Syariah}

Asuransi syariah disebut juga dengan asuransi ta'awun yang artinya tolong-menolong atau saling membantu. Prinsip ini sesuai dengan firman Allah untuk saling tolong-menolong dalam perbuatan positif yang terdapat dalam surat Al Maidah (ayat 2) yang artinya : "dan tolongmenolonglah kamu dalam (mengerjakan) kebajikan dan taqwa, dan jangan tolong-menolong dalam berbuat dosa dan pelanggaran. Dan bertaqwalah kamu kepada Allah, sesungguhnya Allah amat berat siksaNya." 13 Selain itu Firman Allah tentang mempersiapkan hari depan terdapat dalam surat Al Hasyr ayat 18 yang artinya : "Hai orang yang beriman! Bertaqwalah kepada Allah dan hendaklah setiap diri memperhatikan apa yang telah dibuat untuk hari esok (masa depan). Dan bertaqwalah kepada Allah. Sesungguhnya Allah Maha Mengetahui apa yang kamu kerjakan" (QS Al Hasyr ayat 18). ${ }^{14}$

Sedangkan prinsip bermuamalah yang terdapat dalam Hadits Nabi Sallalahu 'Alaihi Wassalam diantaranya:

1. "Barang siapa melepaskan dari seorang muslim suatu kesulitan di dunia, Allah akan melepaskan kesulitan darinya pada hari kiamat ; dan Allah senantiasa menolong hambaNya selama ia (suka) menolong saudaranya" (HR Muslim dari Abu Hurairah).

2. "Perumpamaan orang beriman dalam kasih sayang, saling mengasihi dan mencintai bagaikan tubuh (yang satu) ; Jikalau satu bagian menderita sakit maka bagian lain akan turut menderita" (HR Muslim dari Nu'man bin Basyir).

3. "Seorang mukmin dengan mukmin yang lain ibarat sebuah bangunan, satu bagian menguatkan bagian yang lain" (HR Muslim dari Abu Musa al-Asy'ari).

Untuk memahaminya, kaidah Fiqh menegaskan :

1. "Pada dasarnya, semua bentuk mu'amalah boleh dilakukan kecuali ada dalil yang mengharamkannya".

2. "Segala mudharat harus dihindarkan sedapat mungkin".

3. "Segala mudharat (bahaya) harus dihilangkan".

\section{E. Pengertian Asuransi dan Asuransi Syariah}

Ad-diyah 'ala al-aqilah merupakan istilah yang cukup masyhur dalam kitab-kitab fiqh, yang dianggap oleh sebagian ulama sebagai cikal bakal konsep asuransi syariah. Al-aqilah berasal dari kebiasaan suku Arab jauh sebelum Islam datang. Al-aqilah bahkan tertuang dalam piagam Madinah. Sudah menjadi kebiasaan suku Arab zaman dahulu, jika salah satu anggota suku 
terbunuh oleh anggota suku lain, pewaris korban akan dibayar uang darah (ad-diyah) sebagai kompensasi oleh saudara terdekat dari pembunuh. Saudara terdekat dari pembunuh disebut aqilah. Sistem aqilah disahkan oleh Rasulullah dan menjadi hukum Islam.

Asuransi adalah pertanggungan yang merupakan perjanjian antara dua pihak yang bersepakat yaitu si pembayar iuran dan si pemberi jaminan, apabila terjadi sesuatu kepada si pembayar iuran masalah kecelakaan atau kematian. ${ }^{15}$

Dalam pengertian bahasa Arab, asuransi disebut juga Támin, penanggung disebut Múamin, sedangkan tertanggung disebut Mustamin. Mentäminkan sesuatu artinya seseorang membayar atau menyerahkan uang cicilan untuk ahli warisnya dengan mendapatkan sejumlah uang sebagaimana telah disepakati. ${ }^{16}$

Dalam Kitab Undang-Undang Hukum Dagang disebutkan Asuransi atau pertanggungan adalah perjanjian dimana penanggung mengikat diri terhadap tertanggung dengan memperoleh premi, untuk memberikan kepadanya ganti rugi karena suatu kehilangan, kerusakan atau tidak mendapat keuntungan yang diharapkan, yang mungkin akan dapat diderita karena suatu peristiwa yang tidak pasti. ${ }^{17}$

Pengertian asuransi yang lain dapat dikemukan dalam hukum positif di Indonesia, yaitu pada Undang-Undang Nomor 2 tahun 1992 tentang Usaha Perasuransian. Dalam Undangundang tersebut Asuransi atau Pertanggungan adalah perjanjian antara dua pihak atau lebih, dengan mana pihak penanggung mengikatkan diri kepada tertanggung, dengan menerima premi asuransi, untuk memberikan penggantian kepada tertanggung karena kerugian, kerusakan, atau kehilangan keuntungan yang diharapkan, atau tanggung jawab hukum kepada pihak ketiga yang mungkin akan diderita tertanggung, yang timbul dari suatu peristiwa yang tidak pasti, atau untuk memberikan suatu pembayaran yang didasarkan atas meninggal atau hidupnya seseorang yang dipertanggungkan. ${ }^{18}$ Objek asuransi adalah benda dan jasa, jiwa dan raga, kesehatan manusia, tanggung jawab hukum, serta semua kepentingan lainnya yang dapat hilang, rusak, rugi, dan atau berkurangnya nilai. ${ }^{19}$

Fatwa Dewan Syariah Nasional No: 21/DSN/MUI/X/2001 tentang Pedoman Umum Asuransi Syariah mengatakan bahwa yang dimaksud dengan Asuransi Syariah (Tämin, Takaful, atau Tadhamun) adalah usaha saling melindungi dan tolong menolong diantara sejumlah orang/ pihak melalui investasi melalui aset dan/atau tabarru' yang memberikan pola pengembalian untuk menghadapi resiko tertentu melalui akad (perikatan) yang sesuai dengan syariah. ${ }^{20}$

Dari batasan-batasan yang dikemukakan di atas dapat dirumuskan pengertian tentang Asuransi syariah yaitu sebuah sistem dimana para partisipan/anggota/peserta mendonasikan/

15 Kamus Umum Bahasa Indonesia, JS Badudu, Pustaka Sinar Harapan, Jakarta,1984

16 M.Syakir Sula, Penegertian Asuransi Syariah (At Tämin), Syakirsula.com

17 Pasal 246 Kitab Undang-Undang Hukum Dagang (KUHD)

18 Pasal 1 Ayat (1) Undang-Undang Nomor 2 Tahun 1992 tentang Usaha Perasuransian

19 Pasal 1 Ayat (2), Undang-Undang Nomor 2 Tahun 1992 tentang Usaha Perasuransian

20 Ketentuan umum angka 1 Fatwa Dewan Syariah Nasional No : 21/DSN/MUI/X/2001 tentang Pedoman Umum Asuransi Syariah. 
menghibahkan sebagian atau seluruh kontribusi yang akan digunakan untuk membayar klaim, jika terjadi musibah yang dialami oleh sebagian partisipan/anggota/peserta.

Dengan demikian Peranan Perusahaan ini hanyalah sebatas pengelolaan operasional perusahaan asuransi serta investasi dari dana-dana/kontribusi yang diterima/dilimpahkan kepada perusahaan. Dengan kata lain asuransi syariah bersifat saling melindungi dan tolong menolong yang disebut dengan "ta'awun", yaitu prinsip hidup saling melindungi dan tolong menolong atas dasar ukhuwah islamiyah antara sesama anggota peserta asuransi syariah dalam menghadapi resiko.

Asuransi yang selama ini dikenal mayoritas masyarakat Indonesia, bukan merupakan asuransi yang dikenal para pendahulu dari kalangan ahli fiqh, dan tidak pula dari kalangan para sahabat yang membahas hukumnya. Jenis asuransi ini lebih dikenal sebagai asuransi non syariah/konvensional. Adapun perbedaan dengan jenis asuransi syariah, diantaranya :

1. Pada asuransi non syariah/konvensional terdapat jahalah (ketidaktahuan) dan ghoror (ketidakpastian) dimana tidak diketahui siapa yang mendapat keuntungan atau kerugian pada saat berakhirnya periode asuransi.

2. Di dalamnya terdapat riba atau minimal subhat riba. Hal ini akan terlihat lebih jelas dalam asuransi jiwa, dimana seseorang yang membeli polis asuransi membayar sejumlah kecil dana/ premi dengan harapan mendapatkan uang yang lebih besar di masa mendatang. Akan tetapi bisa saja dia tidak mendapatkannya. Jadi pada hakekatnya transaksi ini adalah tukar menukar uang, dan dengan adanya tambahan uang yang dibayarkan, jelas ini mengandung unsur riba.

3. Jenis asuransi ini termasuk perjudian (gambling), karena salah satu pihak membayar lebih sedikit harta untuk mendapatkan harta lebih banyak dengan cara untung-untungan atau tanpa pekerjaan. Contoh pada asuransi kecelakaan, jika terjadi kecelakaan korban berhak mendapat harta/santunan yang dijanjikan, tetapi jika tidak maka ia tidak akan mendapatkan apapun. ${ }^{21}$

Dengan melihat ketiga hal tersebut, dapat dikatakan bahwa dalam transaksi asuransi non syariah/konvensional yang kita kenal belum sesuai dengan fiqh Islam. Prinsip táawun yang ada dalam asuransi syariah tidak terdapat dalam jenis asuransi tersebut. Asuransi syariah dengan perjanjian awal yang jelas dan transparan, dimana dana dan premi asuransi yang terkumpul (dana tabarru) akan dikelola secara profesional oleh perusahaan asuransi melalui investasi syar'i sesuai dengan prinsip syariah. Pada akhirnya semua dana yang dikelola tersebut (dana tabarru) nantinya akan dipergunakan untuk menghadapi dan mengantisipasi terjadinya musibah/ bencana/klaim yang terjadi diantara peserta asuransi.

Sedangkan menurut Ma’ruf Amin, selaku Ketua Badan Pelaksana Harian Dewan Syariah Nasional nilai lebih asuransi syariah bila dibandingkan dengan asuransi konvensional adalah:

1. Asuransi konvensional menerapkan kontrak jual beli atau biasa disebut tabaduli, sedangkan asuransi syariah menggunakan kontrak takafuli atau tolong menolong antara nasabah satu

21 Anonim, Info Asuransi, http://www.asuransisyariah.net/ 
dengan nasabah yang lain ketika dalam kesulitan. Jadi dalam asuransi syariah saling berbagi resiko (risk sharing), sedangkan pada asuransi konvensional terjadi transfer resiko (risk transferring) dari nasabah kepada perusahaan asuransi.

2. Pengelolaan dana dalam asuransi syariah dapat terhindar dari unsur yang diharamkan dalam Islam, yaitu riba, ghoror, dan maysir. Untuk itu perusahaan asuransi memegang amanah dalam menginvestasikan dana nasabah sesuai dengan prinsip syariah.

3. Jika nasabah asuransi syariah mengajukan klaim, dana klaim berasal dari dana tabarru' (premi asuransi yang terkumpul) dari seluruh peserta asuransi, sedangkan klaim asuransi konvensional dana berasal dari perusahaan asuransinya.

4. Karena konsepnya adalah dana wadiah (titipan), peserta asuransi syariah bisa mendapatkan uangnya kembali meski belum jatuh tempo. Berbeda dengan asuransi konvensional dana bisa hangus kalau belum jatuh tempo. ${ }^{22}$

\section{F. Perbedaan Mendasar Asuransi Non Syariah/Konvensional dengan asuransi Syariah.}

M. Syakir Sula mengemukakan sejumlah perbedaan mendasar antara Asuransi Konvensional dengan Asuransi Syariah sebagai berikut : ${ }^{23}$

\begin{tabular}{|l|l|l|l|}
\hline No & Prinsip & Asuransi Konvensional & Asuransi Syariah \\
\hline 1 & Konsep & $\begin{array}{l}\text { Perjanjian antara dua pihak atau leb- } \\
\text { in, dengan mana pihak penanggung } \\
\text { mengikatkan diri kepada tertanggu- } \\
\text { ng, dengan menerima premi asur- } \\
\text { ansi, untuk memberikan pergantian } \\
\text { kepada tertanggung }\end{array}$ & $\begin{array}{l}\text { Sekumpulan orang yang saling } \\
\text { membantu, saling menjamin dan } \\
\text { bekerjasama dengan cara mas- } \\
\text { ing-masing mengeluarkan tabarru' }\end{array}$ \\
\hline 2 & Asal-usul & $\begin{array}{l}\text { Dari masyarakat Babilonia 4000- } \\
\text { 3000 SM yang dikenal dengan per- } \\
\text { janjian Hammurabi, dan tahun 1668 } \\
\text { M di cofee house London sebagai } \\
\text { cikal-bakal asuransi konvensional }\end{array}$ & $\begin{array}{l}\text { Dari Al Aqilah, kebiasaan suku arab } \\
\text { jauh sebelum Islam datang, kemudi- } \\
\text { an disahkan oleh Rasulullah menjadi } \\
\text { hukum Islam, bahkan telah tertuang } \\
\text { dalam konstitusi pertama di dunia } \\
\text { (Konstitusi Madinah) yang dibuat } \\
\text { langsung oleh Rasulullah }\end{array}$ \\
\hline 3 & Sumber Hukum & $\begin{array}{l}\text { Bersumber dari pikiran manusia dan } \\
\text { kebudayaan. Berdasarkan hukum } \\
\text { positif, hukum alami dan contoh se- } \\
\text { belumnya }\end{array}$ & $\begin{array}{l}\text { Bersumber dari wahyu Illahi. Sum- } \\
\text { ber hukum dalam syariah Islam ada- } \\
\text { lah Al Qur'an, Sunnah, ljma', Fatwa } \\
\text { Sahabat, Qiyas, Istihsan, Urf, dan } \\
\text { Mashalih Mursalah }\end{array}$ \\
\hline 4 & $\begin{array}{l}\text { Maysir, Gharar, dan } \\
\text { Riba }\end{array}$ & $\begin{array}{l}\text { Tidak selaras dengan syariah Islam } \\
\text { karena adanya maysir, gharar, dan } \\
\text { riba ; hal yang diharamkan dalam } \\
\text { Muamalah }\end{array}$ & $\begin{array}{l}\text { Bersih dari adanya praktik maysir, } \\
\text { gharar, dan riba }\end{array}$ \\
\hline
\end{tabular}

22 Ma'ruf Amin, dalam Info Asuransi Syariah, http://www.asuransisyariah.net/2008/08/lebih-adil-denganasuransi-syariah.html

23 M.Syakir Sula, dalam dalam Abdul Ghofur Anshori, Asuransi Syariah di Indonesia (Regulasi dan Operasionalisasinya di dalam Kerangka Hukum Positif di Indonesia),2007, UII Press, Yogyakarta, hal 17-18 


\begin{tabular}{|c|c|c|c|}
\hline 5 & $\begin{array}{l}\text { Dewan Pengawas } \\
\text { Syariah (DPS) }\end{array}$ & $\begin{array}{l}\text { Tidak ada, sehingga dalam prakti- } \\
\text { knya bertentangan dengan kaidah- } \\
\text { kaidah syara' }\end{array}$ & $\begin{array}{l}\text { Ada, yang berfungsi untuk men- } \\
\text { gawasi pelaksanaan operasional } \\
\text { perusahaan agar terbebas dari } \\
\text { praktik-praktik muamalah yang ber- } \\
\text { tentangan dengan prinsip-prinsip } \\
\text { syariah }\end{array}$ \\
\hline 6 & Akad & $\begin{array}{l}\text { Akad jual beli (akad mu'awadah, } \\
\text { akad idz'aan, akad ghara, dan akad } \\
\text { mulzin) }\end{array}$ & $\begin{array}{l}\text { Akad tabarru' dan akad tijarah (mud- } \\
\text { harabah, wakalah, wadiah, syirkah } \\
\text { dan sebagainya) }\end{array}$ \\
\hline 7 & Jaminan/Risk & $\begin{array}{l}\text { Transfer of risk, dimana terjadi trans- } \\
\text { fer resiko dari tertanggung kepada } \\
\text { penanggung }\end{array}$ & $\begin{array}{l}\text { Sharing of risk, dimana terjadi pros- } \\
\text { es saling menanggung antara satu } \\
\text { peserta dengan peserta lainnya } \\
\text { (ta'awun) }\end{array}$ \\
\hline 8 & Pengelolaan dana & $\begin{array}{l}\text { Tidak ada pemisahan dana, yang } \\
\text { berakibat pada terjadinya dana han- } \\
\text { gus (untuk produk saving live) }\end{array}$ & $\begin{array}{l}\text { Pada produk-produk saving life ter- } \\
\text { jadi pemisahan dana, yaitu dana } \\
\text { tabarru'/derma dan dana peserta se- } \\
\text { hingga tidak mengenal istilah dana } \\
\text { hangus. Sedangkan untuk term in- } \\
\text { surance (life) dan general insurance } \\
\text { semuanya bersifat tabarru' }\end{array}$ \\
\hline 9 & Investasi & $\begin{array}{l}\text { Bebas melakukan investasi da- } \\
\text { lam batas-batas ketentuan perun- } \\
\text { dang-undangan, dan tidak terbatasi } \\
\text { pada halal dan haramnya obyek atau } \\
\text { sistem investasi yang digunakan }\end{array}$ & $\begin{array}{l}\text { Dapat melakukan investasi sesuai } \\
\text { ketentuan perundang-undangan, } \\
\text { sepanjang tidak bertentangan den- } \\
\text { gan prinsip-prinsip syariah, bebas } \\
\text { dari riba dan tempat-tempat investa- } \\
\text { si terlarang }\end{array}$ \\
\hline 10 & Kepemilikan dana & $\begin{array}{l}\text { Dana yang terkumpul dari premi } \\
\text { peserta seluruhnya menjadi milik } \\
\text { perusahaan dan perusahaan bebas } \\
\text { menggunakan, serta menginvesta- } \\
\text { sikan ke manapun }\end{array}$ & $\begin{array}{l}\text { Dana yang terkumpul dari peserta } \\
\text { dalam bentuk iuran atau kontribusi, } \\
\text { merupakan milik peserta (shohibul } \\
\text { maal), perusahaan hanya sebagai } \\
\text { pemegang amanah (mudharib) da- } \\
\text { lam mengelola dana tersebut }\end{array}$ \\
\hline 11 & Unsur premi & $\begin{array}{l}\text { Unsur premi terdiri dari tabel mortal- } \\
\text { itas (mortality tables), bunga (inter- } \\
\text { est), beaya asuransi (insurance cost) }\end{array}$ & $\begin{array}{l}\text { luran atau kontribusi terdiri dari un- } \\
\text { sur tabarru'dan tabungan (yang ti- } \\
\text { dak mengandung unsur riba). Tabar- } \\
\text { ru' juga dihitung dari tabel mortali- } \\
\text { tas, tetapi tanpa perhitungan bunga } \\
\text { teknik }\end{array}$ \\
\hline 12 & Loading & $\begin{array}{l}\text { Loading pada asuransi konvensional } \\
\text { cukup besar terutama diperuntukkan } \\
\text { bagi premi agen, bisa menyerap } \\
\text { premi asuransi tahun pertama dan } \\
\text { kedua. Karena itu nilai tunai tahun } \\
\text { pertama dan kedua biasanya belum } \\
\text { ada (masih hangus) }\end{array}$ & $\begin{array}{l}\text { Pada bagian asuransi syariah, load- } \\
\text { ing (komisi agen) tidak dibebankan } \\
\text { kepada peserta, tetapi dari dana } \\
\text { pemegang saham. Namun sebagian } \\
\text { yang lainnya mengambil dari sekitar } \\
20-30 \% \text { saja dari premi tahun per- } \\
\text { tama. Dengan demikian nilai tunai } \\
\text { tahun pertama sudah terbentuk }\end{array}$ \\
\hline
\end{tabular}




\begin{tabular}{|l|l|l|l|}
\hline 13 & $\begin{array}{l}\text { Sumber pembayaran } \\
\text { klaim }\end{array}$ & $\begin{array}{l}\text { Sumber biaya klaim adalah dari re- } \\
\text { kening perusahaan, sebagai kon- } \\
\text { sekuensi penanggung terhadap ter- } \\
\text { tanggung. Murni bisnis dan tidak ada } \\
\text { nuansa spiritual }\end{array}$ & $\begin{array}{l}\text { Sumber pembayaran klaim diper- } \\
\text { oleh dari rekening tabarru', yaitu pe- } \\
\text { serta saling menanggung. Jika salah } \\
\text { satu peserta mendapat musibah, } \\
\text { maka peserta lainnya ikut menang- } \\
\text { gung bersama resiko }\end{array}$ \\
\hline 14 & Sistem akuntansi & $\begin{array}{l}\text { Menganut konsep asuransi accrual } \\
\text { basis, yaitu proses akuntasi yang } \\
\text { mengakui terjadinya peristiwa atau } \\
\text { keadaan non kas, dan mengakui } \\
\text { pendapatan, peningkatan asset, } \\
\text { expensis, liabilities, dalam jumlah } \\
\text { ketentuan yang baru akan diteriman } \\
\text { dalam waktu yang akan datang }\end{array}$ & $\begin{array}{l}\text { Menurut konsep akuntansi cash ba- } \\
\text { sis, mengakui apa yang benar-benar } \\
\text { telah ada, sedangkan accrual basis } \\
\text { diangap bertentangan dengan } \\
\text { syariah karena mengakui adanya } \\
\text { pendapatan, harta, beban utang } \\
\text { yang akan terjadi di masa yang akan } \\
\text { datang. Sementara apakah itu be- } \\
\text { nar-benar dapat terjadi hanya Allah } \\
\text { yang tahu }\end{array}$ \\
\hline 15 & Keuntungan & $\begin{array}{l}\text { Keuntungan yang diperoleh dari sur- } \\
\text { plus underwriting, komisi reasuransi } \\
\text { dan hasil investasi seluruhnya ada- } \\
\text { lah keuntungan perusahaan }\end{array}$ & $\begin{array}{l}\text { Profit yang diperoleh dari surplus } \\
\text { underwriting, komisi reasuransi dan } \\
\text { hasil investasi bukan seluruhnya } \\
\text { menjadi milik perusahaan, tetapi } \\
\text { dilakukan bagi hasil (mudharabah) } \\
\text { dengan peserta }\end{array}$ \\
\hline Misi dan visi & $\begin{array}{l}\text { Misi yang diemban dalam asuran- } \\
\text { Secara garis besar misi utama dari } \\
\text { asuransi konvensional adalah misi } \\
\text { ekonomi dan misi sosial }\end{array}$ & $\begin{array}{l}\text { si syariah adalah misi akidah, misi } \\
\text { ibadah (ta'awun), misi ekonomi, dan } \\
\text { misi pemberdayaan umat (sosial) }\end{array}$ \\
\hline
\end{tabular}

Sedangkan Abdul Ghofur Anshori sendiri mengemukakan tujuh perbedaan mendasar anatara asuransi konvensional dengan asuransi syariah, yaitu: ${ }^{24}$

1. Asuransi syariah memiliki Dewan Pengawas Syariah (DPS) yang bertujuan mengawasi produk yang dipasarkan dan sekaligus terhadap pengelolaan investasi dana yang terkumpul dari premi yang dibayarkan oleh pesrta, sedangkan dalam asuransi konvensional tidak ada dewan sejenis

2. Akad yang dilaksanakan pada asuransi syariah berdasarkan tolong-menolong (akad ta'awuniyah), sedangkan pada asuransi konvensional berdasarkan pada akad jual beli

3. Investasi dana pada asuransi syariah berdasarkan akad bagi hasil (mudharabah), sedangkan pada asuransi konvensional memakai sistem bunga sebagai dasar perhitungan sehingga termasuk riba

4. Kepemilikan dana pada asuransi syariah merupakan hak peserta. Perusahaan hanya sebagai pemegang amanah untuk mengelolanya. Pada asuransi konvensional, dana yang terkumpul dari nasabah berupa premi menjadi milik perusahaan, sehingga perusahaan bebas menentukan alokasi investasinya 
5. Dalam mekanismenya, asuransi syariah tidak mengenal dana hangus sebagaimana yang terjadi pada asuransi konvensional. Jika pada masa kontrak peserta tidak dapat melanjutkan pembayaran premi dan ingin mengundurkan diri sebelum masa reversing period, maka dana yang dimasukkan dapat diambil kembali, kecuali sebagian dana yang memang telah diniatkan untuk tabarru'

6. Pembayaran klaim pada asuransi syariah diambil dari dana tabarru' (dana kebajikan) seluruh peserta yang sejak awal telah diikhlaskan bahwa ada penyisihan dana yang akan dipakai sebagai dana tolong-menolong diantara peserta apabila terjadi musibah. Sedangkan pada asuransi konvensional pembayaran klaim diambilkan dari rekening dana perusahaan.

7. Pembagian keuntungan pada asuransi syariah dibagi antara perusahaan dengan peserta sesuai prinsip bagi hasil (mudharabah) dengan proporsi yang telah ditentukan, sedangkan pada asuransi konvensional seluruh keuntungan menjadi hak milik perusahaan.

\section{G. Prinsip Asuransi Syariah (Takaful)}

Asuransi syariah memiliki prinsip yang tidak sama dengan asuransi konvensional. Para ulama dan ahli ekonomi Islam mengemukakan bahwa asuransi syariah ditegakkan atas tiga prinsip utama, yaitu :

1. Prinsip bekerjasama dan saling membantu

Sesama peserta harus semakin meningkatkan kepeduliannya dalam upaya meringankan beban saudaranya yang lain. "dan tolong-menolonglah kamu dalam (mengerjakan) kebajikan dan taqwa, dan jangan tolong-menolong dalam berbuat dosa dan pelanggaran.(QS Al Maidah:2). Nabi SAW mengajarkan bahwa siapa yang meringankan beban saudaranya, Allah akan meringankan kebutuhan hidupnya.(HR Bukhari \& Muslim)

2. Prinsip saling bertanggung jawab.

Banyak Hadits Nabi SAW yang mengajarkan bahwa hubungan umat beriman dalam rasa kasih sayang satu sama lain, ibarat satu badan yang apabila yang satu anggota badannya terganggu atau kesakitan, maka seluruh badan akan ikut merasakan, tidak dapat tidur, dan terasa panas. Islam mengajarkan mensucikan jiwa dengan mengurangkan sebanyak mungkin perasaan mementingkan diri sendiri. Rizki Allah yang berupa harta benda hendaklah disyukuri, jangan hanya dinikmati diri sendiri, tetapi digunakan juga untuk memenuhi kepentingan masyarakat, meringankan beban penderitaan, dan meningkatkan taraf hidup mereka.

Hadits Nabi SAW tersebut diantaranya :

a. "Kedudukan hubungan persaudaraan dan perasaan orang-orang beriman antara satu dengan lain seperti satu tubuh (jasad) apabila satu dari anggotanya tidak sehat, maka akan berpengaruh kepada seluruh tubuh" (HR. Bukhari dan Muslim).

b. "Seorang mukmin dengan mukmin yang lain (dalam suatu masyarakat) seperti sebuah bangunan di mana tiap-tiap bagian dalam bangunan itu mengukuhkan bagian-bagian yang lain"(HR. Bukhari dan Muslim). 
c. "Setiap kamu adalah pemikul tanggung jawab dan setiap kamu bertanggung jawab terhadap orang-orang yang di bawah tanggung jawabmu" (HR. Bukhari dan Muslim).

d. "Seseorang tidak dianggap beriman sehingga ia mengasihi saudaranya sebagaimana ia mengasihi dirinya sendiri"(HR. Bukhari).

Rasa tanggung jawab terhadap sesama merupakan kewajiban setiap muslim. Rasa tanggung jawab ini tentu lahir dari sifat saling menyayangi, mencintai, saling membantu dan merasa mementingkan kebersamaan untuk mendapatkan kemakmuran bersama dalam mewujudkan masyarakat yang beriman, takwa dan harmonis.

3. Prinsip saling melindungi penderitaan satu dengan yang lain.

Semua peserta asuransi harus berprinsip bahwa tidak sempurna iman seseorang sehingga ia tidur nyenyak dengan perut kenyang, sedangkan tetangganya menderita kelaparan. Komitmen membela dan saling mensejahterakan sangat diharapkan tercipta melalui keikutsertaan pada takaful.

Sebagaimana firman Allah dalam Al Qur'an yang artinya : "(Allah) yang telah memberi makanan kepada mereka untuk menghilangkan lapar dan mengamankan mereka dari ketakutan." (QS Al Quraisy ayat 4), dan Hadits Nabi SAW yang artinya : "Sesungguhnya seseorang yang beriman ialah siapa yang dapat memberi keselamatan dan perlindungan terhadap harta dan jiwa raga umat manusia." (HR. Ibnu Majah). ${ }^{25}$

Selain ketiga prinsip yang telah diuraikan di atas, Karnaen A.Perwataatmaja menambahkan satu prinsip yang lain yaitu prinsip menghindari unsur gharar, maysir, dan riba.

Gharar/Uncertainty (ketidakpastian). Menurut M.Syafi'i Antonio ada dua bentuk, yaitu Pertama, bentuk akad syariah yang melandasi penutupan polis. Secara konvensional, kontrak atau perjanjian dalam asuransi jiwa dapat dikategorikan sebagai akad tabaduli atau akad pertukaran yaitu pertukaran pembayaran premi dengan uang pertanggungan. Secara harfiah dalam akad pertukaran harus jelas berapa yang dibayarkan dan berapa yang diterima. Keadaan ini menjadi rancu (gharar) karena kita tahu berapa yang akan diterima (sejumlah uang pertanggungan), tetapi tidak tahu berapa yang akan dibayarkan (sejumlah seluruh premi) karena hanya Allah yang tahu kapan seseorang akan meninggal. Dalam konsep syariah keadaan ini akan lain karena akad yang digunakan adalah akad takafuli atau tolong-menolong dan saling menjamin di mana semua peserta asuransi menjadi penolong/ penjamin satu sama lainnya.

Kedua, Sumber dana pembayaran klaim dan keabsahan syar'i penerima uang klaim itu sendiri. Dalam konsep asuransi konvensional, peserta tidak mengetahui dari mana dana pertanggungan yang diberikan perusahaan asuransi berasal. Peserta hanya tahu jumlah pembayaran klaim yang akan diterimanya. Dalam konsep takaful, setiap pembayaran premi sejak awal akan dibagi dua, masuk ke rekening pemegang polis dan satu lagi dimasukkan ke rekening khusus peserta yang harus diniatkan tabarru' atau derma untuk membantu saudaranya yang lain. Dengan kata lain, dana klaim dalam konsep takaful diambil dari dana tabarru' yang merupakan kumpulan dana 
shadaqah dari para peserta. ${ }^{26}$

Maysir/Gambling (Untung-untungan). Di sini ada salah satu pihak yang untung namun di lain pihak justru mengalami kerugian. Unsur ini dalam asuransi konvensional terlihat apabila selama masa perjanjian peserta tidak mengalami musibah atau kecelakaan, maka peserta tidak berhak mendapatkan apa-apa termasuk premi yang disetornya. Sedangkan, keuntungan diperoleh ketika peserta yang belum lama menjadi anggota (jumlah premi yang disetor sedikit) menerima dana pembayaran klaim yang jauh lebih besar. Dalam konsep takaful, apabila peserta tidak mengalami kecelakaan atau musibah selama menjadi peserta, maka ia tetap berhak mendapatkan premi yang disetor kecuali dana yang dimasukkan ke dalam dana tabarru'.

Unsur Riba. Hal ini tercermin dalam cara perusahaan asuransi konvensional melakukan usaha dan investasi di mana meminjamkan dana premi yang terkumpul atas dasar bunga. Dalam konsep takaful dana premi yang terkumpul diinvestasikan dengan prinsip bagi hasil yaitu mudharabah atau musyarakah. Riba (bunga) dalam pengelolaan premi asuransi tidak sesuai dengan prinsip dasar transaksi syariah sebagaimana ditetapkan dalam fatwa Majelis Ulama Indonesia (MUI) pada tanggal 16 Desember 2003 yang menyatakan bahwa bunga termasuk dalam kategori riba. Fatwa tentang bunga adalah riba bukanlah wacana baru bagi umat Islam, karena sebelumnya MUI telah beberapa kali mencetuskan wacana tersebut. Fatwa yang pertama dikeluarkan pada tahun 1990 yang diikuti dengan berdirinya bank syariah pertama yaitu Bank Muamalat Indonesia, dan yang kedua pada tahun 2000 di mana Dewan Syariah Nasional mengeluarkan fatwa bahwa penerapan suku bunga bertentangan dengan syariah Islam. Hal ini kemudian diikuti dengan Fatwa Dewan Syariah Nasional No. 21/DSN-MUI/X/2001 tentang Pedoman Umum Asuransi Syariah. ${ }^{27}$

\section{H. Fatwa tentang Pedoman Umum Asuransi Syariah}

Dewan Syariah Nasional Majelis Ulama Indonesia (DSN-MUI) telah mengeluarkan produk hukum berupa Fatwa Dewan Syariah Nasional No. 21/DSN-MUI/X/2001 tentang Pedoman Umum Asuransi Syariah. Dengan dikeluarkannya Fatwa ini sangat berarti bagi praktik asuransi syariah di Indonesia. Adapun isi dari Fatwa Dewan Syariah Nasional No. 21/DSNMUI/X/2001 tentang Pedoman Umum Asuransi Syariah adalah sebagai berikut:

Pertama, Ketentuan Umum :

1. Asuransi Syariah (Tamin, Takaful atau Tadhamun) adalah usaha saling melindungi dan tolong-menolong di antara sejumlah orang/pihak melalui investasi dalam bentuk aset dan I atau tabarru' yang memberikan pola pengembalian untuk menghadapi resiko tertentu melalui akad (perikatan) yang sesuai dengan syariah.

2. Akad yang sesuai dengan syariah yang dimaksud pada point (1) adalah yang tidak mengandung gharar (penipuan), maysir (perjudian), riba, zhulm (penganiayaan), risywah (suap), barang haram dan maksiat.

26 M.Syafi'I Antonio , Prinsip Dasar Operasi Asuransi Takaful dalam Arbitrase Islam di Indonesia, Badan Arbitrase Muamalat Indonesia, Jakarta, 1994, hal.148

27 http://www.takafulmulia.com/2012/12/prinsip-operasional-asuransi-syariah.html 
3. Akad tijarah adalah semua bentuk akad yang dilakukan untuk tujuan komersial.

4. Akad tabarru' adalah semua bentuk akad yang dilakukan dengan tujuan kebajikan dan tolong-menolong, bukan semata untuk tujuan komersial.

5. Premi adalah kewajiban peserta Asuransi untuk memberikan sejumlah dana kepada perusahaan asuransi sesuai dengan kesepakatan dalam akad.

6. Klaim adalah hak peserta Asuransi yang wajib diberikan oleh perusahaan asuransi sesuai dengan kesepakatan dalam akad.

Kedua, Akad dalam Asuransi :

1. Akad yang dilakukan antara peserta dengan perusahaan terdiri atas akad tijarah dan / atau akad tabarru'.

2. Akad tijarah yang dimaksud dalam ayat (1) adalah mudharabah. Sedangkan akad tabarru' adalah hibah.

3. Dalam akad, sekurang-kurangnya harus disebutkan

a. hak \& kewajiban peserta dan perusahaan;

b. cara dan waktu pembayaran premi;

c. jenis akad tijarah dan / atau akad tabarru'serta syarat-syarat yang disepakati, sesuai dengan jenis asuransi yang diakadkan.

Ketiga, Kedudukan Para Pihak dalam Akad Tijarah dan Tabarru'

4. Dalam akad tijarah (mudharabah), perusahaan bertindak sebagai mudharib (pengelola) dan peserta bertindak sebagai shahibul mal (pemegang polis);

5. Dalam akad tabarru' (hibah), peserta memberikan hibah yang akan digunakan untuk menolong peserta lain yang terkena musibah. Sedangkan perusahaan bertindak sebagai pengelola dana hibah.

\section{Keempat, Ketentuan dalam Akad Tijarah \& Tabarru'}

6. Jenis akad tijarah dapat diubah menjadi jenis akad tabarru' bila pihak yang tertahan haknya, dengan rela melepaskan haknya sehingga menggugurkan kewajiban pihak yang belum menunaikan kewajibannya.

7. Jenis akad tabarru' tidak dapat diubah menjadi jenis akad tijarah.

Kelima, Jenis Asuransi dan Akadnya

1. Dipandang dari segi jenis asuransi itu terdiri atas asuransi kerugian dan asuransi jiwa.

2. Sedangkan akad bagi kedua jenis asuransi tersebut adalah mudharabah dan hibah. Keenam, Premi

1. Pembayaran premi didasarkan atas jenis akad tijarah dan jenis akad tabarru'

2. Untuk menentukan besarnya premi perusahaan asuransi syariah dapat menggunaka rujukan, misalnya tabel mortalita untuk asuransi jiwa dan tabel morbidita untuk asuransi kesehatan, dengan syarat tidak memasukkan unsur riba dalam penghitungannya.

3. Premi yang berasal dari jenis akad mudharabah dapat diinvestasikan dan hasil investasinya dibagi-hasilkan kepada peserta. 
4. Premi yang berasal dari jenis akad tabarru' dapat diinvestasikan.

Ketujuh, Klaim

1. Klaim dibayarkan berdasarkan akad yang disepakati pada awal perjanjian.

2. Klaim dapat berbeda dalam jumlah, sesuai dengan premi yang dibayarkan.

3. Klaim atas akad tijarah sepenuhnya merupakan hak peserta, dan merupakan kewajiban perusahaan untuk memenuhinya.

4. Klaim atas akad tabarru', merupakan hak peserta dan merupakan kewajiban perusahaan, sebatas yang disepakati dalam akad.

Kedelapan, Investasi

1. Perusahaan selaku pemegang amanah wajib melakukan investasi dari dana yang terkumpul.

2. Investasi wajib dilakukan sesuai dengan syariah.

Kesembilan : Reasuransi

Asuransi syariah hanya dapat melakukan reasuransi kepada perusahaan reasuransi yang berlandaskan prinsip syari'ah.

Kesepuluh : Pengelolaan

1. Pengelolaan asuransi syariah hanya boleh dilakukan oleh suatu lembaga yang berfungsi sebagai pemegang amanah.

2. Perusahaan Asuransi Syariah memperoleh bagi hasil dari pengelolaan dana yang terkumpul atas dasar akad tijarah (mudharabah).

3. Perusahaan Asuransi Syariah memperoleh ujrah (fee) dari pengelolaan dana akad tabarru' (hibah).

Kesebelas : Ketentuan Tambahan

1. Implementasi dari fatwa ini harus selalu dikonsultasikan dan diawasi oleh DPS

2. Jika salah satu pihak tidak menunaikan kewajibannya atau jika terjadi perselisihan diantara para pihak, maka penyelesaiannya dilakukan melalui Badan Arbitrasi Syari'ah setelah tidak tercapai kesepakatan melalui musyawarah. Fatwa ini berlaku sejak tanggal ditetapkan, dengan ketentuan jika di kemudian hari ternyata terdapat kekeliruan, akan diubah dan disempurnakan sebagaimana mestinya.

\section{Penyelesaian Sengketa Asuransi Syariah}

Pangkal tolak dari adanya suatu sengketa adalah karena munculnya konflik kepentingan antara satu atau beberapa orang dengan satu atau beberapa orang yang lainnya. Hal serupa juga bisa terjadi pada bidang asuransi syariah. Sengketa timbul seringkali berkaitan dengan klaim ditolak dengan berbagai alasan. Padahal klaim merupakan sarana bagi tertanggung untuk mendapatkan manfaat asuransi sebagaimana telah diperjanjikan dalam polis asuransi.

Terdapat beberapa alternatif penyelesaian sengketa di bidang asuransi syariah yang bisa dipilih oleh para pihak untuk dituangkan dalam Polis Asuransi yang dibuat diantara mereka. Secara umum penyelesaian sengketa terdiri dari dua macam cara, yaitu secara litigasi dan non litigasi. Secara non litigasi apabila para pihak memilih sarana penyelesaian sengketa berupa 
Arbitrase dan Alternatif Penyelasaian Sengketa, sedangkan secara litigasi adalah penyelasaian sengketa melalui jalur pengadilan, yang dalam hal ini adalah melalui Peradilan Agama.

Dalam Polis Asuransi biasanya telah disebutkan hal terkait dengan penyelesaian sengketa. Hal pertama yang disebut adalah keinginan bersama untuk melakukan musyawarah untuk mufakat apabila di kemudian hari terjadi sengketa dalam hal pelaksanaan perjanjian atau kontrak yang telah disepakati bersama. Apabila jalan musyawarah mengalami kegagalan ada jalur lain yang diperjanjikan baik itu melalui lembaga Arbitrase atau langsung ke lembaga pengadilan.

Islam sebagai Agama yang lebih mencintai perdamaian dan menjadi pedoman bagi pemeluknya. Dalam hal sengketa muamalah yang timbul akan lebih bijaksana jika diselesaikan melalui cara-cara damai. Untuk itu para pihak sebaiknya lebih mengedepankan menempuh upaya musyawarah untuk mufakat ketika menghadapi sengketa. Dalam hal musyawarah untuk mufakat tidak tercapai, baru para pihak dapat menempuh upaya lain yaitu melalui jalur negosiasi, mediasi, arbitrase, dan menempatkan jalur litigasi melalui pengadilan sebagai jalan yang terkhir.

Pasal 1 (ayat 1) Undang-Undang Nomor 30 tahun 1999 tentang Arbitrase dan Alternatif Penyelesaian Sengketa mengatakan bahwa Arbitrase adalah cara penyelesaian suatu sengketa perdata di luar peradilan umum yang didasarkan pada perjanjian arbitrase yang dibuat secara tertulis oleh para pihak yang bersengketa. ${ }^{28}$ Perjanjian dapat dibuat sebelum terjadinya sengketa (pactum de compromittendo) maupun sesudah terjadinya sengketa (akta kompromis). Perjanjian arbitrase adalah suatu kesepakatan berupa klausul arbitrase yang tercantum dalam suatu perjanjian tertulis yang dibuat para pihak sebelum timbul sengketa, atau suatu perjanjian arbitrase tersendiri yang dibuat para pihak setelah timbul sengketa. ${ }^{29}$

Dalam praktiknya, terdapat badan-badan arbitrase yang secara spesifik ditujukan untuk menyelesaikan sengketa-sengketa tertentu oleh pihak-pihak tertentu. Badan arbitrase khusus itu diantaranya adalah Badan Arbitrase Muamalah Indonesia (BAMUI) atau saat ini berubah nama menjadi Badan Arbitrase Syariah Nasional (BASYARNAS) yang didirikan oleh Majelis Ulama Indonesia (MUI). Badan ini berwenang menyelesaikan sengketa muamalah yang dialami oleh umat Islam, misalnya sengketa antara Perusahaan Asuransi Syariah dengan pesertanya. Basyarnas berwenang menyelesaikan sengketa ekonomi syariah, termasuk asuransi syariah sepanjang para pihak memperjanjikan dalam Akad (Polis Asuransi) yang mereka buat.

Pasal 49 Undang-Undang Nomor 3 tahun 2006 mengatakan :"Pengadilan agama bertugas dan berwenang memeriksa, memutus, dan menyelesaikan perkara di tingkat pertama antara orang-orang yang beragama Islam di bidang: perkawinan; waris; wasiat; hibah; wakaf; zakat; infaq; shadaqah; dan ekonomi syari'ah." ${ }^{30}$ Dengan demikian penyelesaian sengketa sengketa secara litigasi diselesaiakan melalui lembaga peradilan agama.

28 Pasal 1 (ayat 1) Undang-Undang Nomor 30 tahun 1999 tentang Arbitrase dan Alternatif Penyelesaian Sengketa

29 Pasal 1 (ayat 3) Undang-Undang Nomor 30 tahun 1999 tentang Arbitrase dan Alternatif Penyelesaian Sengketa

30 Pasal 49 Undang-Undang Nomor 3 tahun 2006 tentang Perubahan atas Undang-Undang Nomor 7 tahun 1989 tentang Peradilan Agama 


\section{J. Peluang Prospektif Asuransi Syariah}

Kebutuhan akan lembaga keuangan yang bernuansakan Islami semakin bertambah kuat seiring dengan berkembangnya sektor industri jasa keuangan secara umum. Untuk memenuhi permintaan umat Islam dalam bertraksaksi dalam bidang ekonomi agar terhindar dari perbuatan yang bersifat maysir, ghoror, dan riba diperlukan pengelolaan lembaga keuangan syariah, dan salah satu diantaranya adalah asuransi syariah. Dewasa ini perkembangan lembaga asuransi syariah mulai menunjukkan kemajuannya, meskipun keberadaannya belum sepopuler lembaga keuangan syariah yang lain seperti perbankan syariah.

Asuransi syariah di Indonesia memiliki peluang yang prospektif mengingat jumlah penduduk Indonesia yang beragama Islam lebih dari 180 Juta. Kenyataannya penduduk yang beragama Islam tersebut mulai ada kesadaran untuk mengekspresikan identitas kemuslimannya melalui berbagai macam cara. Sebagai contoh perusahaan yang bergerak di bidang makanan dan minuman mulai memasang label halal pada produknya, pakaian dan asesorinya yang beridentitaskan Islam, perjalanan haji dan umroh, lembaga pendidikan dan media masa yang Islami terus menerus meningkat utamanya pada dua decade terakhir ini. Disamping itu sebagian umat Islam menginginkan segala interaksi muamalah yang dilakukannya dalam upaya mencapai kesejahteraannya, sesuai dengan syariah.

Firmanzah menyebut mengenai sejumlah tantangan yang perlu diperhatikan dalam mendorong ekonomi syariah nasional, termasuk di dalamnya asuransi syariah, yaitu :

Pertama, Kesiapan sumber daya manusia yang andal di sektor ini. Industri ini diperkirakan membutuhkan setidaknya 200.000 tenaga kerja yang memiliki kompetensi di industri perbankan dan keuangan syariah. Di beberapa negara bahkan telah diterapkan sertifikasi Islamic Finance Qualification (IFQ) yang dikeluarkan oleh Inggris, Libanon, Bahrain, Dubai, dan Malaysia. Kedua, Pemahaman masyarakat terhadap instrumen perbankan dan keuangan syariah yang relatif rendah. Hal ini diharapkan mendorong penetrasi informasi kepada masyarakat luas atas manfaat ekonomi syariah dan mendorong penggunaan instrumen-instrumen ekonomi syariah. Ketiga, Masih terbatasnya perguruan tinggi yang mengajarkan ekonomi Islam akibat kelangkaan ahliahli di bidang ini. Keempat, Koordinasi kelembagaan yang mengatur industri perbankan dan keuangan nasional yang masih relatif terbatas. Kehadiran OJK diharapkan mampu membenahi dan meningkatkan koordinasi kelembagaan serta mendorong perkembangan ekonomis syariah di Indonesia. Kelima, Pengembangan ekonomi syariah memerlukan keterpaduan seluruh pihak, baik industri, pemerintah dan masyarakat. ${ }^{31}$

Sedangkan Halim Alamsyah menyebutkan bahwa Indonesia memiliki potensi untuk menjadi global player keuangan syariah sangat besar, dengan alasan :

Pertama, Jumlah penduduk muslim yang besar menjadi potensi nasabah industri keuangan syariah ; Kedua, Prospek ekonomi yang cerah, tercermin dari pertumbuhan ekonomi yang relatif tinggi (kisaran 6,0\% - 6,5\%) yang ditopang oleh fundamental ekonomi yang solid. Ketiga, Peningkatan sovereign credit rating Indonesia menjadi investment grade yang akan meningkatkan

31 Firmanzah, http://economy.okezone.com/read/2013/11/18/279/898464/geliat-ekonomi-syariah 
minat investor untuk berinvestasi di sektor keuangan domestik, termasuk industri keuangan syariah; Keempat, memiliki sumber daya alam yang melimpah yang dapat dijadikan sebagai underlying transaksi industri keuangan syariah. ${ }^{32}$

Agus Hariyadi menyebutkan mengenai beberapa aspek yang dapat menjadi peluang, ancaman (tantangan), kekuatan dan kelemahan dalam memperluas jaringan bisnis asuransi Islam di Indonesia. Adapun aspek yang menjadi peluang diantaranya :

1. Keunggulan konsep asuransi Islam dapat memenuhi tuntutan rasa keadilan dari masyarakat.

2. Jumlah penduduk beragama Islam di Indonesia lebih dari 180 juta orang.

3. Meningkatnya kesadaran untuk bermuamalah sesuai dengan syariah tumbuh subur khususnya pada masyarakat golongan menengah.

4. Meningkatnya kebutuhan jasa asuransi karena perkembangan ekonomi umat.

5. Tumbuhnya lembaga keuangan syariah (LKS) lainnya seperti bank dan rekadana. ${ }^{33}$

Asuransi syariah (takaful) di Indonesia masih berada dalam tahap perkenalan. Umumnya, industri pada tahap ini masih memperkenalkan disain produk dasar, konsumen masih harus diyakinkan untuk membeli produk. Biaya pemasaran untuk membangun pengetahuan konsumen relatif masih tinggi. Untuk itu sinergi dari berbagai pihak mulai dari industri asuransi, pemerintah, dan masyarakat sangat diharapkan.

\section{K. Kesimpulan}

Indonesia merupakan negara yang mayoritas penduduknya memeluk agama Islam, namun demikian perkembangan produk-produk yang berprinsip syariah baru berkembang lima tahun terakhir, dan salah satu diantaranya adalah produk asuransi syariah. Geliat bisnis syariah kini kian menggiurkan, sehingga memikat sejumlah perusahaan untuk mengelola asuransi dengan basis sistem syariah. Sekalipun belum didukung oleh sebuah regulasi dalam bentuk undangundang tentang asuransi syariah, akan tetapi perkembangannya cukup menggembirakan. Hal ini diantaranya karena adanya dukungan dari Majelis Ulama Indonesia yang telah mengeluarkan Fatwa Dewan Syari'ah Nasional tentang Pedoman Umum Asuransi Syariah, meskipun keberadaannya tidak diakui dalam hukum positif di Indonesia.

Masa depan asuransi syariah di Indonesia masih terbuka lebar. Pertumbuhan ekonomi yang kuat dikombinasikan dengan naiknya tingkat tabungan dan berkembangnya perekonomian kelas menengah merupakan pertanda baik untuk industri asuransi syariah. Disamping faktor penduduk yang mayoritas beragama Islam, pertumbuhan ekonomi yang terus-menerus meningkat, stabilitas politik, dan kecenderungan meningkatnya masyarakat untuk menabung menjadi pertanda yang baik bagi meningkatnya perkembangan asuransi syariah di Indonesia.

Melihat peluang yang begitu besar, maka sudah seharusnya sosialisasi tentang asuransi

32 Halim Alamsyah, Perkembangan dan Prospek Perbankan Syariah Indonesia: Tantangan Dalam Menyongsong MEA 2015, Milad ke-8 Ikatan Ahli Ekonomi Islam (IAEI),http://www.bi.go.id/id/ruang-media/pidato-dewangubernur

33 Agus Hariyadi, dalam Rohman Soleh, Prospek Asuransi Islam di Indonesia,html 
syariah perlu dilakukan secara lebih serius dan komprehensif, sehingga sangat perlu untuk mensinergikan kepentingan berbagai pihak seperti industri asuransi sendiri, pemerintah (regulator), ulama, akademisi, serta lembaga-lembaga yang fokus terhadap perkembangan bisnis syariah. Untuk menjawab besarnya peluang yang ada, perlu adanya sumber daya manusia yang professional dan memadai, disertai dengan dukungan modal, ditambah payung hukum yang mendukung.

\section{Bibliography}

Anonim, Info Asuransi, http://www.asuransisyariah.net/

Anshori,Abdul Ghofur, Asuransi Syariah di Indonesia (Regulasi dan Operasionalisasinya di dalam Kerangka Hukum Positif di Indonesia,2007, UII Press, Yogyakarta

Antonio, M.Syafi'i , Prinsip Dasar Operasi Asuransi Takaful dalam Arbitrase Islam di Indonesia, Badan Arbitrase Muamalat Indonesia, Jakarta, 1994

Badudu, JS, Kamus Umum Bahasa Indonesia, Pustaka Sinar Harapan, Jakarta,1984

Fatwa Dewan Syariah Nasional No : 21/DSN/MUI/X/2001 tentang Pedoman Umum Asuransi Syariah.

Firmanzah, http://economy.okezone.com/read/2013/11/18/279/898464/geliat-ekonomisyariah

http://www.takafulmulia.com/2012/12/prinsip-operasional-asuransi-syariah.html

Halim Alamsyah, Perkembangan dan Prospek Perbankan Syariah Indonesia: Tantangan Dalam Menyongsong MEA 2015, Milad ke-8 Ikatan Ahli Ekonomi Islam (IAEI),http://www. bi.go.id/id/ruang-media/pidato-dewan-gubernur

Info Asuransi Syariah, http://www.asuransisyariah.net/2008/08/lebih-adil-dengan-asuransisyariah.html

Kitab Undang-Undang Hukum Dagang (KUHD)

Laporan Penelitian Asuransi Syariah, Badan Litbang Diklat Kumdil Mahkamah Agung RI, 2009

Soleh, Rohman, Prospek Asuransi Islam di Indonesia, html

Sula, M.Syakir, Penegertian Asuransi Syariah (At Tämin), syakirsula.com

Undang-Undang Nomor 21 tahun 2008 tentang Perbankan Syariah 
Undang-Undang Nomor 3 tahun 2006 tentang Perubahan atas Undang-Undang Nomor 7 tahun 1989 tentang Peradilan Agama

Undang-Undang Nomor 30 tahun 1999 tentang Arbitrase dan Alternatif Penyelesaian Sengketa

Undang-Undang Nomor 2 Tahun 1992 tentang Usaha Perasuransian

Undang-Undang Nomor 10 tahun 2004 tentang Pembentukan Peraturan Perundang-Undangan. 